\title{
KEKHUSUSAN PENGATURAN PEMERIKSAAN DAN PEMBUKTIAN PERCERAIAN DALAM HUKUM ACARA PENGADILAN AGAMA
}

\author{
Oleh:
}

\author{
I Gusti Ayu Agung Ari Krisnawati ${ }^{1}$ \\ Fakultas Hukum Universitas Udayana
}

\begin{abstract}
Abstrak
Hukum Acara yang berlaku di Pengadilan Agama adalah hukum acara perdata yang berlaku pada Pengadilan dalam lingkungan Peradilan Umum, kecuali yang telah diatur secara khusus dalam Undang-Undang Peradilan Agama.

Pengaturan secara khusus dalam bidang pemeriksaan perceraian di lingkungan Pengadilan Agama adalah dalam cara mengajukan permohonan cerai talak oleh suami dan gugatan perceraian oleh isteri harus diajukan ke pengadilan agama yang daerah hukumnya meliputi kediaman isteri, kecuali isteri dengan sengaja meninggalkan tempat kediaman yang ditentukan bersama tanpa ijin suami. Pemeriksaan cerai talak dan gugatan perceraian dilakukan dalam sidang tertutup dan biaya perkara perceraian dibebankan kepada pemohon atau kepada penggugat.

Kekhususan pembuktian dalam Hukum Acara Pengadilan Agama adalah pembuktian permohonan cerai talak, pembuktian dalam gugatan perceraian berdasarkan pada alasan salah satu pihak mendapat pidana penjara, pembuktian dalam gugatan perceraian didasarkan alasan tergugat mendapat cacat badan atau penyakit dengan akibat tidak dapat menjalankan kewajiban sebagai suami, pembuktian gugatan perceraian didasarkan alasan syiqaq, pembuktian gugatan berdasarkan alasan zinah. Untuk macam-macam perceraian yang tidak diatur pembuktiannya oleh Undang-Undang Peradilan Agama diberlakukan pembuktian dari HIR, RBG.
\end{abstract}

Kata kunci : Pengaturan, Kekhususan, Pemeriksaan, Pembuktian, Pengadilan Agama.

\section{Abstract}

Procedural law applicable to the Religious Court is the civil procedural law which applicable to the Courts in the public judicature area, except as specifically regulated in the Law on Religious Court.

Specific provisions on the divorce examination in the Religious Court can be seen through the way to submit for talak divorce by the husband and the divorce claim from the wife shall be submitted to the Religious Court within the jurisdiction of the wife's domicile, except if the wife intentionally leaving the residence jointly determined by her and the husband without her husband's permission, examination of the talak divorce and divorce claim in a closed session, the divorce court fees charged to the applicant or to the plaintiff.

Specificity of authentications in Procedural Law of Religious Courts can be seen on the authentication of the talak divorce submission, authentication in a divorce claim based on the ground that one party gets imprisonment, authentication in a divorce claim based on the ground that the defendant is disabled or disease which result in the inability to perform the duty as a husband, authentication in a divorce claim based on the ground of syiqaq, authentication in a divorce claim based on the ground of adultery. For all kinds of authentications of divorce that is not regulated by the Law on Religious Courts then the authentications set forth in HIR or RBG shall be applied.

Keywords: Arrangement, Specificity, Inspection, Verification, Religious Court.

\section{PENDAHULUAN}

Indonesia sebagai Negara Hukum wajib menjunjung tinggi hukum yang berlaku di negara Indonesia. Oleh karena itu semua tindakan negara melalui pemerintahan maupun lembaga-lembaga negara yang lainnya harus berlandaskan hukum atau harus dapat dipertanggungjawabkan secara hukum. Lembaga peradilan adalah salah satu unsur dari sistem Negara Hukum yang bertugas menyelesaikan pelanggaran-pelanggaran hukum yang terjadi demi untuk tegaknya hukum yang berlaku.

\footnotetext{
${ }^{1}$ Gusti Ayu Agung Ari Krisnawati adalah dosen pada Bagian Hukum Acara Fakultas Hukum Universitas Udayana.
} 

g. Infaq
h. Sedekah, dan
i. Ekonomi Syari'ah".

Khusus dalam bidang perkawinan yang dimaksud oleh UU No.3 Tahun 2006, adalah tentang perkawinan yang diatur dalam UU No.1 Tahun 1974 Tentang Perkawinan dimana salah satu masalah dari perkawinan ini adalah putusnya perkawinan karena perceraian.

Perceraian yang diselesaikan oleh Pengadilan Agama ini mencakup perceraian dengan cerai talak, cerai gugat dan cerai dengan alasan zina. Hukum acara yang berlaku dalam penyelesaian sengketa perkawinan yang menyebabkan perceraian ini sebagaimana disebutkan dalam Pasal 54 UUPA adalah hukum acara perdata yang berlaku pada Pengadilan dalam lingkungan peradilan umum, kecuali yang telah diatur secara khusus dalam undang-undang ini.

Pengecualian pengaturan proses pemeriksaan di Pengadilan Agama ini sesuai dengan tugas dan wewenang Pengadilan Agama yang khusus mengadili jenis perkara menurut agama Islam serta mewujudkan hukum materiil Islam. Dengan demikian, walaupun dari segi asas-asas hukum acara ada prinsip-prinsip kesamaan secara umum, namun secara khusus ada perbedaan antara hukum Acara Peradilan Umum dan Hukum Acara Peradilan Agama.

Ketentuan-ketentuan yang bersifat khusus dan dimuat dalam pasal-pasal Undang-Undang Peradilan Agama ini tidak dijelaskan sebagai ketentuan khusus. Tulisan ini akan menguraikan penunjukan ketentuan-ketentuan khusus tersebut berdasarkan hasil penelitian normatif yang mencakup sistematik hukum $^{2}$ dari peristiwa hukum proses perceraian, sekaligus tentang pembuktian dari peristiwa terjadinya perceraian tersebut.

Adapun beberapa rumusan permasalahan yang akan dibahas dalam tulisan ini ialah meliputi:

1. Bagaimanakah putusnya perkawinan karena perceraian menurut Hukum Islam dan pengaturan menurut hukum positif Indonesia?

2. Bagaimanakah kekhususan pengaturan pemeriksaan perceraian dalam Hukum Acara Pengadilan Agama?

3. Bagaimanakah kehususan pengaturan pembuktian terjadinya perceraian dalam Hukum Acara Peradilan Agama?

\section{PEMBAHASAN}

\subsection{Putusnya Perkawinan Karena Perceraian Menurut Hukum Islam dan Pengaturannya Dalam Hukum Positif Di Indonesia}

Salah satu asas dari suatu perkawinan menurut Syari'at dalam Islam, adalah perkawinan untuk selama-lamanya. Oleh karana itu agama Islam mengharamkan perkawinan yang tujuannya untuk sementara, dalam waktu-waktu yang tertentu sekedar untuk melepaskan hawa nafsu saja, seperti nikah

2 Soerjono Soekanto dan Sri Mamuji. 1985. Penelitian Hukum Normatif. Jakarta: Penerbit CV. Rajawali, h.80. 
telah dijatuhkan talak tiga, bekas suami tidak diperbolehkan untuk mengawini bekas isterinya, kecuali bekas isteri sebelumnya pernah kawin dengan laki-laki lain (Al Baqarah ayat 230). ${ }^{6}$

\section{Ad.2) Talak Ta'lik}

Talak ta'lik artinya penggantungan talak, yaitu adanya ikrar atau perjanjian suami yang dicantumkan dalam surat nikah dan diikrarkan setelah akad nikah. Dalam ikrarnya, suami menggantungkan terjadinya suatu talak atas isterinya, apabila dikemudian hari suami melanggar salah satu atau semua yang telah diikrarkan, sebagai berikut:

1. Meninggalkan isteri selam 6 bulan berturut-turut, kecuali menjalankan tugas Negara;

2. Sengaja tidak memberi nafkah selama 3 bulan berturut-turut;

3. Melakukan penyiksaan badaniah dan rohaniah kepada isteri;

4. Menambang isteri dalam masa 6 bulan berturut-turut.

\section{Ad.3) Syiqaq}

Perselisihan antara suami isteri dengan jalan didamaikan melalui wakil-wakil (hakam) dari keluarga mereka.

Ad.4) Ila

Adalah bila seorang suami bertekad untuk tidak mau mencampuri isterinya dan melaknatinya.

\section{Ad.5) Zhihar}

Zhihar artinya punggung. Bila seorang suami bersumpah yang ditujukan kepada isterinya, bahwa isterinya itu baginya sama dengan punggung ibunya. Di tanah Arab, menyamakan isteri dengan punggung ibunya berarti sudah tidak mau lagi mencampurinya.

\section{Ad.6) Fahisyah}

Adalah perbuatan yang mencemarkan nama baik keluarga yang dilakukan oleh suami atau isteri. Misalnya: menipu, mencuri, zina, berjudi dan sebagainya. Perceraian tidak langsung terjadi, melainkan yang berbuat diinsyafkan terlebih dahulu. Kalau tidak berhasil menginsyafkan isteri yang melakukan perbuatan, suami bisa menjatuhkan talak, sebaliknya apabila suami yang melakukan perbuatan, isteri bisa meminta suami menjatuhkan talak.

\section{Ad.7) Khuluk}

Yang dimaksud khuluk adalah bercerai dengan mengganti kerugian, umumnya diartikan karena penebusan oleh pihak isteri. Khuluk dilakukan bila suami isteri tidak akan dapat bersatu kembali atau satu sama lainnya sudah saling membenci.

\section{Ad.8) Fasakh}

Perceraian yang disebabkan karena suami atau isteri cacad, salah satu pihak mendapatkan hukuman yang berat, suami tidak memberikan nafkah, meninggalkan tempat kediaman bersama,

\footnotetext{
6 Ibid., h.57.
} 
2. Perceraian hanya dapat dilakukan di depan sidang pengadilan setelah pengadilan atau Pengadilan Agama yang bersangkutan berusaha dan tidak berhasil mendamaikan kedua belah pihak (Pasal 39 UU No 1 Tahun 1974, Pasal 115 KHI).

3. Untuk melakukan perceraian harus ada cukup alasan, bahwa antara suami isteri itu tidak akan dapat hidup rukun sebagai suami isteri (Pasal 39 UU No. 1 Tahun 1974, Pasal 116 KHI).

4. Dari ketentuan tata cara perceraian yang disebutkan dalam Pasal $39 \mathrm{~s} / \mathrm{d}$ Pasal 41 UU No 1 Tahun 1974, Pasal 117 dan Pasal 129 KHI dapat dinyatakan adanya 2 macam perceraian, yaitu:
a. cerai talak
b. cerai gugat

5. Alasan - alasan untuk terjadinya perceraian disebutkan dalam Pasal 19 PP No. 9 Tahun 1975, sebagai berikut:

a. Salah satu pihak berbuat zina atau menjadi pemabuk, pemadat, penjudi dan lain sebagainya yang sukar disembuhkan.

b. Salah satu pihak meninggalkan pihak lainnya selama 2 (dua) tahun berturut-turut tanpa ijin pihak lainnya dan tanpa alasan yang sah atau karena hal lain diluar kemampuannya.

c. Salah satu pihak mendapat hukuman penjara 5 (lima) tahun atau hukuman yang lebih berat setelah perkawinan berlangsung.

d. Salah satu pihak melakukan kekejaman atau penganiayaan berat yang membahayakan pihak yang lain.

e. Salah satu pihak mendapat cacat badan atau penyakit dengan akibat tidak dapat menjalankan kewajibannya sebagai suami-isteri.

f. Antara suami dan isteri terus-menerus terjadi perselisihan dan pertengkaran dan tidak ada harapan akan hidup rukun lagi dalam rumah tangga.

Alasan-alasan terjadinya perceraian huruf a sampai dengan f ini juga disebutkan dalam Pasal 116 KHI dengan 2 (dua) tambahan alasan, yaitu karena:

1. Suami melanggar taklik-talak

2. Peralihan Agama atau murtad yang menyebabkan terjadinya ketidakrukunan dalam rumah tangga.

Adanya dua tambahan ketentuan alasan terjadinya perceraian yang tidak disebutkan dalam UU No 1 Tahun 1974, sesuai dengan jiwa UU Perkawinan yang bersifat nasional sebagaimana disebutkan dalam penjelasan umumnya. Sebagai undang-undang perkawinan yang bersifat nasional, undangundang ini meletakkan asas-asas hukum perkawinan nasional yang bisa diperlakukan bagi berbagai macam suku bangsa dan golongan penduduk. Selain itu menampung prinsip-prinsip yang memberikan landasan hukum perkawinan yang menjadi pegangan dan telah berlaku bagi berbagai golongan masyarakat, ${ }^{10}$ yang dituangkan dalam peraturan yang lebih khusus.

Berdasarkan analisis secara konstruksi dengan melakukan acontrario, macam-macam perceraian yang merupakan alasan terjadinya perceraian menurut hukum Islam, seperti terjadinya perceraian

${ }^{10}$ K. Wantjik Saleh. 1978. Hukum Perkawinan Indonesia. Yogyakarta: Penerbit Ghalia Indonesia, h.3 
Kekhususan Pengaturan Pemeriksaan dan Pembuktian Perceraian Dalam Hukum Acara Pengadilan Agama I Gusti Ayu Agung Ari Krisnawati

juga mengatur bagaimana cara Pengadilan Agama tersebut menyelesaikan perkaranya, untuk mewujudkan hukum materiil Islam yang menjadi kekuasaan Peradilan Agama". ${ }^{11}$

Rumusan Hukum Acara Peradilan Agama ini sesuai dengan penerapan hukum acara pemeriksaan perceraian yang berlandaskan ketentuan umum (hukum acara peradilan umum yang bersumber pada perundang-undangan negara) dan berlandaskan ketentuan khusus (syari'at Islam) yang dapat dideskripsikan sebagai berikut:

1. Hukum acara yang berlaku di Peradilan Umum menentukan: "Gugatan perceraian diajukan oleh suami atau isteri atau kuasanya kepada pengadilan yang daerah hukumnya meliputi tempat kediaman tergugat, kecuali apabila penggugat dengan sengaja meninggalkan tempat kediaman bersama tanpa ijin tergugat".

Ketentuan ini tidak berlaku di lingkungan Peradilan Agama, walaupun diikuti ketentuan umum bahwa: "Setiap perceraian hanya dapat dilakukan di depan sidang pengadilan setelah pengadilan yang bersangkutan berusaha dan tidak berhasil mendamaikan kedua belah pihak", (Pasal 65 UU PA).

Penyimpangan berlakunya ketentuan umum di Pengadilan Agama ini karena menurut hukum Islam ada tiga kualifikasi bentuk perceraian dilihat dari segi orang yang berwenang memutuskan perceraian yaitu: cerai talak, cerai gugat, dan cerai dengan alasan zina ( $L i$ 'an). Pengajuan perkara cerai talak diajukan oleh suami sebagai pemohon, kepada pengadilan yang daerah hukumnya meliputi tempat kediaman termohon (isteri), kecuali apabila isteri dengan sengaja meninggalkan tempat kediaman yang ditentukan bersama tanpa ijin suami (nusyuz). Sedangkan perkara cerai gugat diajukan oleh isteri sebagai penggugat, kepada pengadilan yang daerah hukumnya meliputi tempat kediaman penggugat (isteri), kecuali apabila isteri dengan sengaja meninggalkan tempat kediaman bersama tanpa ijin suami (Pasal 66 ayat (2), Pasal 73 UU PA).

Ketentuan tentang cara mengajukan permohonan talak dan pengajuan gugatan di tempat kediaman isteri, menurut pendapat ahli hukum Islam sesuai dengan jiwa UU Perkawinan di Indonesia untuk melindungi wanita umumnya dan isteri khususnya. Ketentuan ini juga sesuai dengan hukum Islam, yang memberi legitimasi kaum wanita umumnya dan isteri khususnya. Dasar perlindungan ini dengan adanya kenyataan kedudukan isteri di dalam keluarga sebagai subordinasi suaminya, sedangkan posisinya relatif lemah, terutama dalam proses pengambilan keputusan dan hak kontrol di dalam keluarga, termasuk dalam perceraian. ${ }^{12}$

2. Dalam pemeriksaan cerai talak dan cerai gugat di Pengadilan Agama dilakukan dengan sidang tertutup. (Pasal 66 ayat (2), 73 ayat (1) UU PA). Ketentuan khusus ini terkait dengan pandangan menurut hukum agama Islam, bahwa perceraian merupakan "konflik individual", yang tidak etis apabila diketahui oleh pihak yang tidak secara langsung berhubungan dengan pemeriksaan perkara tersebut.

3. Pasal 89 UU PA menentukan, biaya perkara dalam bidang perkawinan dibebankan kepada penggugat atau pemohon, bukan dibebankan kepada pihak yang kalah.

\footnotetext{
11 Roihan A. Rasyid. 1991. Hukum Acara Peradilan Agama. Jakarta: Penerbit Rajawali Pers, h.10.

12 Cik Hasan Bisri. 2000. Peradilan Agama di Indonesia. Jakarta: Penerbit PT. Raja Grafindo Persada, h.259.
} 

c. Persangkaan-Persangkaan
d. Pengakuan
e. Sumpah

Peraturan-peraturan tentang pembuktian dan alat-alat bukti yang terdapat dalam HIR, RBG dan KUH Perdata ini karena merupakan bagian dari hukum acara perdata, maka sesuai dengan Pasal 54 UU PA, juga berlaku di Pengadilan Agama, kecuali yang telah diatur secara khusus dalam UU Peradilan Agama.

Berikut ini diuraikan pembuktian terjadinya perceraian yang diatur secara khusus dalam Undang-Undang PA ialah meliputi:

1. Pembuktian dalam permohonan cerai talak.

Pasal 70 UU PA menentukan: "Pengadilan setelah berkesimpulan bahwa kedua belah pihak tidak mungkn lagi didamaikan dan telah cukup alasan perceraian, maka Pengadilan menetapkan permohonan tersebut dikabulkan".

Kata berkesimpulan dalam Pasal 70 ini dihubungkan dengan pembuktian menurut Undang-Undang Peradilan Umum adalah menggunakan alat bukti persangkaan-persangkaan. Dalam pembuktian dengan alat-alat bukti ini Pengadilan Agama secara khusus bukan menggunakan fakta-fakta apa yang harus disimpulkan, melainkan persangkaan-persangkaan yang disimpulkan hakim berdasarkan fakta-fakta yang diperoleh dipersidangan. Contoh: Hakim dalam menyimpulkan bahwa kedua belah pihak tidak mungkin lagi didamaikan dengan menyimpulkan peristiwa-peristiwa selama proses perkara berlangsung, kedua belah pihak tidak serumah lagi, pernah diusahakan perdamaian tetapi tidak berhasil. Dalam hal menarik kesimpulan telah cukup alasan perceraian, hakim dapat menarik dari peristiwa-peristiwa sebagai berikut: isteri pemboros, isteri senang berjudi, isteri banyak membuat hutang.

2. Pasal 74 UU PA tentang pembuktian dalam gugatan perceraian didasarkan atas alasan salah satu pihak mendapat pidana penjara, yang diajukan melalui gugatan oleh isteri.

Pembuktian disini, dengan petunjuk, bahwa penggugat cukup menyampaikan salinan putusan dari pengadilan yang berwenang dengan disertai keterangan yang menyatakan bahwa putusan itu memperoleh kekuatan hukum tetap. Salinan putusan yang telah memperoleh kekuatan hukum tetap, disamakan dengan akte autentik.

3. Pasal 75 UU PA mengatur pembuktian dalam gugatan perceraian didasarkan atas alasan tergugat mendapat cacat badan atau penyakit dengan akibat tidak dapat menjalankan kewajibannya sebagai suami. Gugatan perceraian dengan alasan ini diajukan oleh isteri.

Pembuktian cacat badan dibebankan kepada suami (tergugat). Pembuktiannya disini, cukup dengan surat keterangan dokter tentang penyakit tergugat sebagai bukti yang sempurna. Untuk membuktikan tidak dapat menjalankan kewajiban sebagai suami, dibebankan kepada isteri (Penggugat). Untuk membuktikan peristiwanya dapat diajukan saksi-saksi yang melihat sendiri kehidupan rumah tangganya. Seperti dari keluarga dekat atau orang yang dekat dengan pihak yang bercerai. Misalnya: anak, orang tua, menantu, mertua, pembantu rumah tangga atau tetangga. 


\subsection{Saran}

1. Agar para pihak yang mengajukan perceraian lebih jelas dalam menghadapi akibat perceraian, diperlukan penjelasan dalam pengaturan alasan-alasan perceraian untuk umat Islam. Alasan mana yang bisa diajukan dengan cerai talak atau cerai gugat. Hal demikian dilakukan, karena seperti, alasan perceraian karena khuluk, pelanggaran talak ta'lik walaupun diputuskan oleh pengadilan, untuk terjadinya perceraian pihak suami harus mengikrarkan talak yang mempunyai batasan-batasan hukum.

2. Terkait pengaturan proses pembuktian dalam hal terjadinya perceraian sebagaimana diatur dalam UU PA, seharusnya dapat diperjelas melalui pengaturan khusus dalam ketentuan penjelasan UU PA.

\section{DAFTAR PUSTAKA}

\section{Buku}

Bisri, Cik Hasan. 2000. Peradilan Agama di Indonesia. Jakarta: Penerbit PT. Raja Grafindo Persada. Muchtar, Kamal. 1974. Asas-asas Hukum Islam Tentang Perkawinan. Jakarta: Penerbit Bulan Bintang. Rasyid, Roihan A. 1991. Hukum Acara Peradilan Agama. Jakarta: Penerbit Rajawali Pers.

Saleh, K.Wantjik. 1978. Hukum Perkawinan Indonesia. Yogyakarta: Penerbit Ghalia Indonesia.

Soekanto, Soerjono dan Mamuji, Sri. 1985. Penelitian Hukum Normatif Suatu Tinjauan Singkat. Jakarta: Penerbit CV. Rajawali.

Subekti. 1977. Hukum Acara Perdata. Bandung: Penerbit Bina Cipta.

Supramono, Gatot. 1993. Hukum Pembuktian Di Peradilan Agama. Bandung: Penerbit Alumni.

\section{Peraturan Perundang-Undangan}

Undang- Undang No.1 Tahun 1974 Tentang Perkawinan, Lembaran Negara Republik Indonesia Tahun 1974 Nomor 1, Tambahan Lembaran Negara Republik Indonesia Nomor 3050

Undang-Undang No. 48 Tahun 2009 Tentang Kekuasaan Kehakiman, Lembaran Negara Republik Indonesia Tahun 2009 Nomor 157, Tambahan Lembaran Negara Republik Indonesia Nomor 5076

Undang-Undang No.50 Tahun 2009 Tentang Perubahan Kedua Atas Undang-Undang No.7 Tahun 1989 Tentang Peradilan Agama, Lembaran Negara Republik Indonesia Tahun 2009 Nomor 159, 


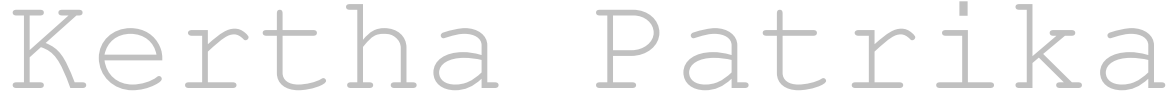

KERTHA PATRIKA

Volume 38, Nomor 3, Desember 2016

Tambahan Lembaran Negara Republik Indonesia Nomor 5078

Peraturan Pemerintah No. 9 Tahun 1975 Tentang Pelaksanaan Undang-Undang No.1 Tahun 1974 Tentang Perkawinan

Instruksi Presiden No.1 Tahun 1991 Tentang Kompilasi Hukum Islam

Kitab Undang-Undang Hukum Perdata (Burgerlijk Wetboek) 